\title{
Communication
}

\section{Pd confined in grass-like graphene layers on monolithic cordierite as the catalyst for hydrogenation of 4-carboxybenzaldehyde}

\author{
Gonggang Liu a, Linyu Yua ${ }^{\text {, }}$ Yuchao Zhu a, Xiaoguang Guo ${ }^{\text {b, Yonghua Zhou }}{ }^{\text {a,* }}$, Hongqi Ye a,\# \\ a College of Chemistry and Chemical Engineering, Central South University, Changsha 410083, Hunan, China \\ b State Key Laboratory of Catalysis, Dalian Institute of Chemical Physics, Chinese Academy of Sciences, Dalian 116023, Liaoning, China
}

A R T I C L E I N F O

Article history:

Received 15 September 2014

Accepted 11 November 2014

Published 20 February 2015

Keywords:

Pd catalyst

Grass-like graphene

4-Carboxybenzaldehyde

Hydrogenation

\begin{abstract}
A B S T R A C T
Pd nanoparticles were confined in grass-like graphene layers on monolithic cordierite by using $\mathrm{NH}_{2}$-ion liquid $\mathrm{C}_{7} \mathrm{H}_{14} \mathrm{ClN}_{3}$ functionalized graphene sheets. These were used as the catalyst for the hydrogenation of 4-carboxybenzaldehyde. The catalyst exhibited high stability compared to Pd/activated carbon catalyst due to the inhibition of Pd leaching and aggregation.
\end{abstract}

(C) 2015, Dalian Institute of Chemical Physics, Chinese Academy of Sciences. Published by Elsevier B.V. All rights reserved.
The hydrogenation of 4-carboxybenzaldehyde (4-CBA) is an important reaction in the purification of crude terephthalic acid (CTA) [1]. Pd-based catalysts have been widely used for this reaction. As the support, most metal oxides, such as $\mathrm{Al}_{2} \mathrm{O}_{3}$ and $\mathrm{SiO}_{2}$, are not suitable for this system due to the acidic property of the CTA solution, which would dissolve the metal oxide. In recent years, a carbon supported Pd catalyst has gained increasing attraction because of the improved stability [2,3]. However, the Pd catalyst still faces several challenges. The most important is the aggregation of $\mathrm{Pd}$ particles under the industrial reaction conditions (7 MPa, $250{ }^{\circ} \mathrm{C}$ ) [4].

In general, there are two main strategies to reduce the aggregation of Pd particles. One is to add a second component, such as a metal, $\mathrm{Ru}[5,6]$ or Pt $[7,8]$, or metal oxides, $\mathrm{TiO}_{2}[9,10]$ and $\mathrm{In}_{2} \mathrm{O}_{3}[11]$, which can form an alloy or form a strong interaction with Pd. However, for the alloyed Pd, the improved stability is often accompanied by decreased activity. For metal oxides, the deposition process must be prudently performed to ensure their high dispersion. The other alternative is to utilize space confinement, for example, encapsulation of Pd particles by porous silica oxide [12] or filling the inner space by CNTs [13]. Therefore, if there is a semi-open surrounding, for instance, a grass-like surface built for the Pd particles, not only Pd particle stabilization but also a high efficiency of mass transfer will be ensured. In this work, we designed a structured catalyst in which Pd nanoparticles were dispersed and stabilized in grass-like graphene layers on monolithic cordierite. This gave high stability and activity to the catalyst for the hydrogenation of 4-CBA.

Graphene (Gr) is an extensively explored carbon material as a catalyst support $[14,15]$. It can spread over a monolithic cordierite through hydrogen bond or electrostatic interaction with the assistance of a polyelectrolyte [16,17]. In this study, we spread $\mathrm{NH}_{2}$-ion liquid $\left(\mathrm{C}_{7} \mathrm{H}_{14} \mathrm{ClN}_{3}\right.$, denoted as $\mathrm{NH}_{2}$-IL) function-

\footnotetext{
*Corresponding author. Tel/Fax: +86-731-88876605; E-mail: zhouyonghua@mail.csu.edu.cn

\# Corresponding author. Tel/Fax: +86-731-88876605; E-mail: yeslab@mail.csu.edu.cn

This work was supported by the National Natural Science Foundation of China (21006129, 21276284 and 21146008).

DOI: 10.1016/S1872-2067(14)60256-4 | http://www.sciencedirect.com/science/journal/18722067 | Chin. J. Catal., Vol. 36, No. 2, February 2015
} 
alized Gr layers on cordierite and further loaded it with Pd. It was found that most Pd particles entered the interlayers of the immobilized Gr layers, denoted as Pd/Gr-N/cordierite. More interestingly, when the $\mathrm{Pd} / \mathrm{Gr}-\mathrm{N} /$ cordierite catalyst was aged under a severe reaction condition similar to the industrial operation, the Gr layers were erected and interconnected to form a grass-like arrangement which generated a space confinement for the Pd particles loaded there. The resulting catalyst, named as aged $\mathrm{Pd} / \mathrm{Gr}-\mathrm{N} /$ cordierite, exhibited a much higher stability for the hydrogenation of 4-CBA than a commercial Pd/C catalyst. The possible mechanism of the formation of the grass-like Gr sheets is shown in Fig. 1.

In a typical experiment, GO (graphene oxide) prepared by the modified Hummers method was reduced by ascorbic acid to obtain $\mathrm{Gr}$ [18]. Then the $\mathrm{NH}_{2}$-IL modified $\mathrm{Gr}$ (denoted as Gr-N) was prepared by keeping $\mathrm{NH}_{2}$-IL and the Gr sheets mixture under sonication for a period of time.

Introducing $\mathrm{NH}_{2}$-IL led to the improved dispersion of $\mathrm{Gr}$ in water (Fig. 2(a)). The reduction of GO to $\mathrm{Gr}$ and subsequent modification of $\mathrm{Gr}$ with $\mathrm{NH}_{2}$-IL was confirmed by FT-IR and UV-Vis (Fig. 2(b), (c)). The characteristic peaks of $\mathrm{NH}_{2}$-IL at $2874 \mathrm{~cm}^{-1}$ (stretching vibration of $\mathrm{NH}_{2}$ forming strong hydrogen bond), $862 \mathrm{~cm}^{-1}$ ( $\mathrm{NH}_{2}$ twisting vibration), 1561, 1460, and $1075 \mathrm{~cm}^{-1}$ (imidazole ring) were observed for Gr-N, which confirmed the presence of $\mathrm{NH}_{2}$-IL on Gr. The UV-Vis spectra showed that a red shift of the Gr peak occurred from 246 to 266 $\mathrm{nm}$ after it was modified by $\mathrm{NH}_{2}$-IL. This indicated that there
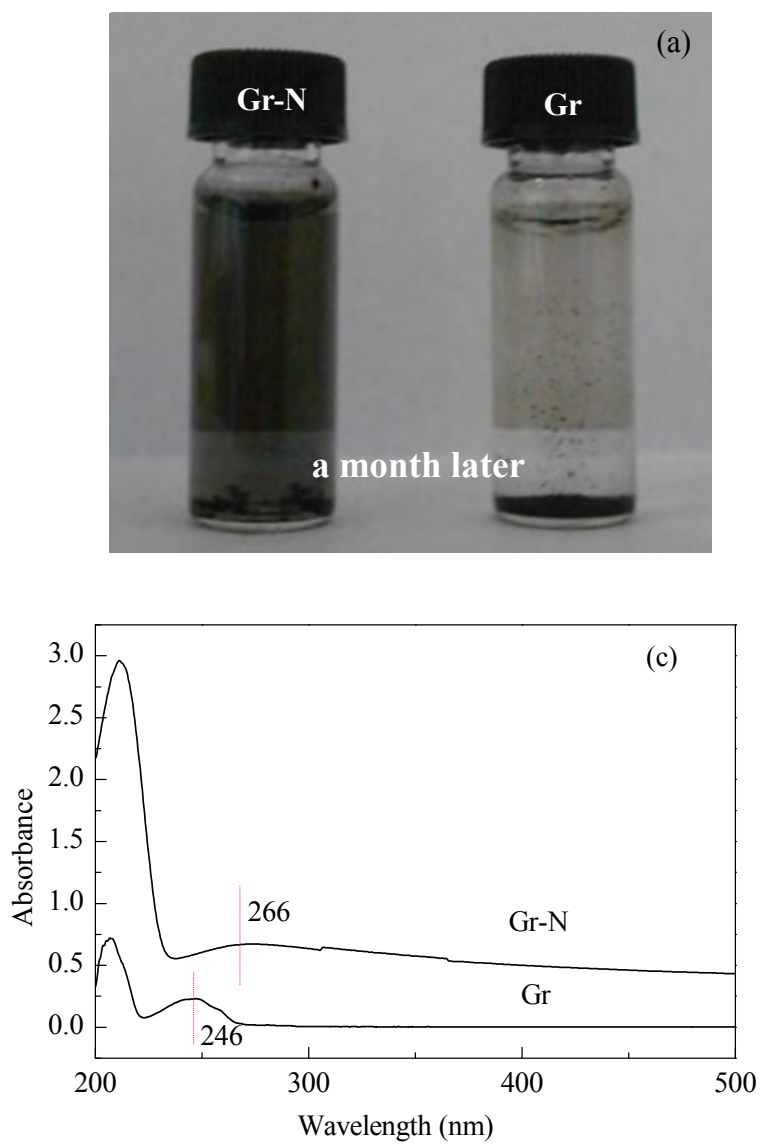

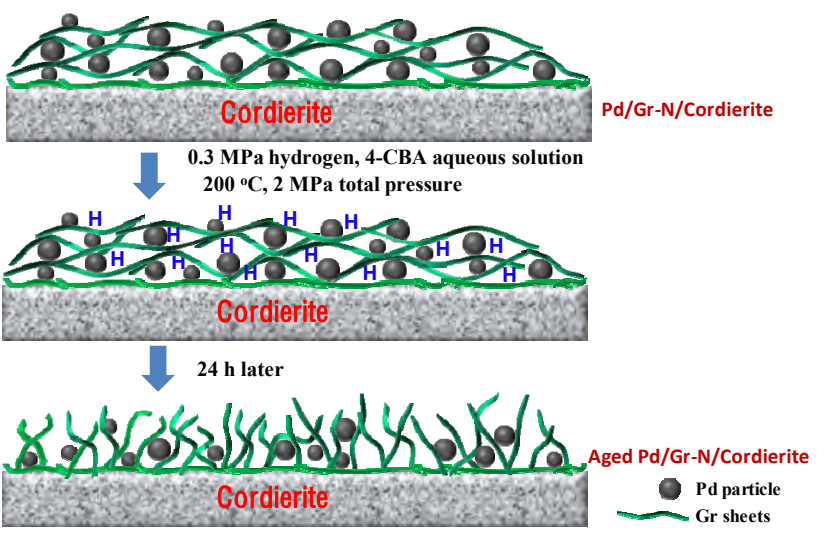

Fig. 1. Preparation of aged $\mathrm{Pd} / \mathrm{Gr}-\mathrm{N} /$ cordierite with grass-like $\mathrm{Gr}$ sheets.

was $\pi-\pi$ non-covalent bonding between the imidazole ring and Gr [19]. The amount of $\mathrm{NH}_{2}$-IL connected to the Gr was evaluated by TGA (Fig. 2(d)). $\mathrm{NH}_{2}$-IL showed an obvious mass loss of $20 \%$ between 100 and $200{ }^{\circ} \mathrm{C}$ due to water loss. Then the $\mathrm{NH}_{2}$-IL started to decompose at $250{ }^{\circ} \mathrm{C}$, and was completely decomposed at $500{ }^{\circ} \mathrm{C}$, with a total mass loss of $65 \%$. Similarly, two mass loss peaks were observed for Gr-N. The mass loss of $6 \%$ below $250{ }^{\circ} \mathrm{C}$ was ascribed to the removal of adsorbed water. From the mass loss between 250 and $500{ }^{\circ} \mathrm{C}$ caused by the decomposition of $\mathrm{NH}_{2}$-IL, the mass percentage of $\mathrm{NH}_{2}$-IL in Gr-N can be estimated to be $8 \%$.
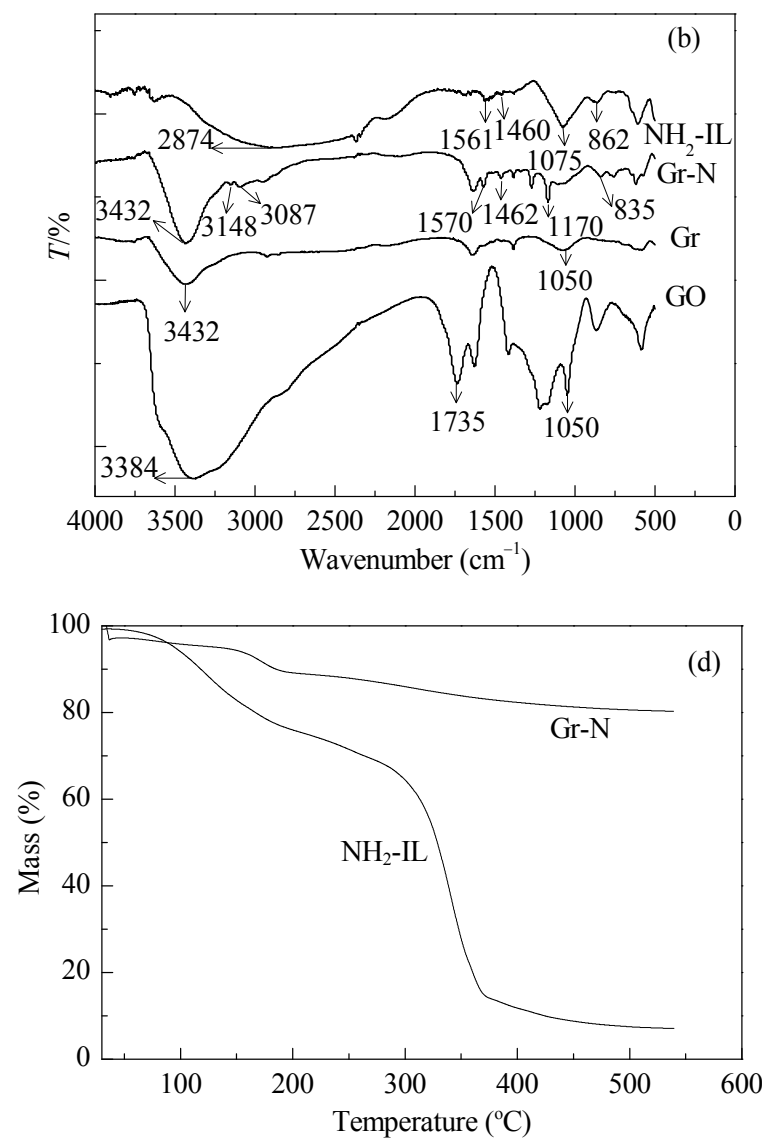

Fig. 2. Digital photos (a), FT-IR spectra (b), UV-Vis spectra (c) and TGA curves (d) of $\mathrm{NH}_{2}-\mathrm{IL}$, Gr, Gr-N, and GO. 

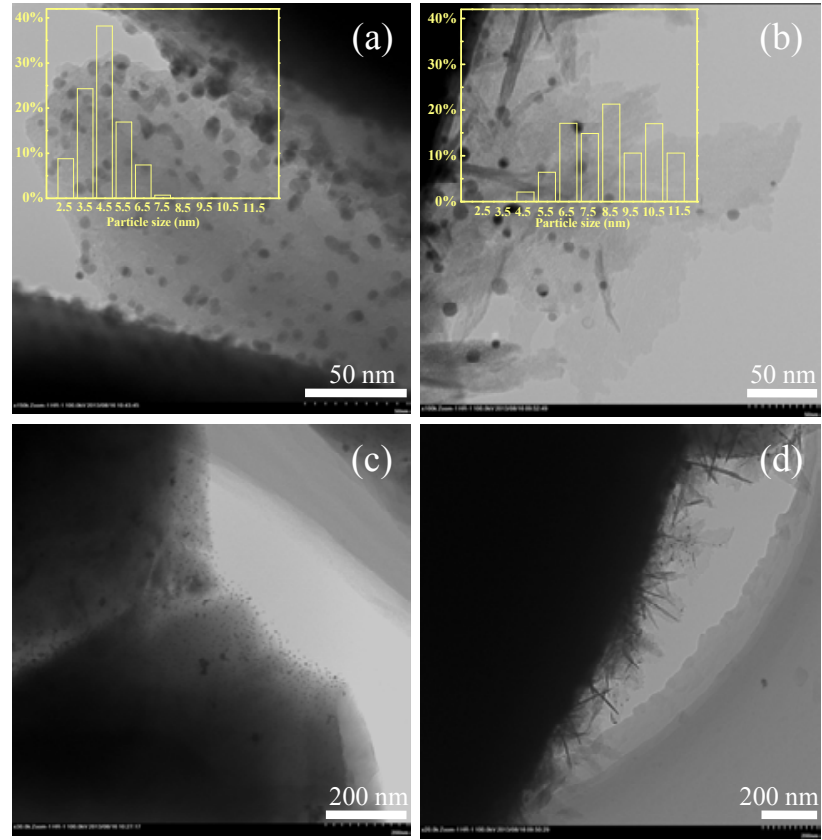

Fig. 3. TEM images of Pd/Gr-N/cordierite catalyst before ((a) and (c)) and after aging $((\mathrm{b})$ and $(\mathrm{d}))$.

TEM images with different intensity of the Pd/Gr-N/cordierite and aged Pd/Gr-N/cordierite catalysts are shown in Fig. 3. As shown in Fig. 3(a) and (b), after aging, the Pd particle size was increased from 2 to $8 \mathrm{~nm}$ to 4 to $12 \mathrm{~nm}$. In addition, a morphology change can be easily observed for the Gr coating. The outer layers of $\mathrm{Gr}$ have been erected and were interlocked to form a grass-like surface. Figure 4 shows the Raman spectra of the $\mathrm{Pd} / \mathrm{Gr}-\mathrm{N} /$ cordierite catalyst before and after aging. Because there is an interference of fluorescence at the wavelength of $532 \mathrm{~nm}$, the measuring wavelength was changed to $785 \mathrm{~nm}$. Normally, the positions of the D band and G band at $532 \mathrm{~nm}$ for Gr are at 1360 and $1600 \mathrm{~cm}^{-1}$ [20]. However, they are shifted to 1375 and $1520 \mathrm{~cm}^{-1}$ at $785 \mathrm{~nm}$. It is known that the D band is related to a disordered and defective carbon structure, while the $\mathrm{G}$ band corresponds to a well-ordered graphite structure [21]. The intensity ratio of the $D$ and $G$ bands $\left(I_{\mathrm{D}} / I_{\mathrm{G}}\right)$ for the aged $\mathrm{Pd} / \mathrm{Gr}-\mathrm{N} /$ cordierite catalyst was 1.77 , and $I_{\mathrm{D}} / I_{\mathrm{G}}$ of

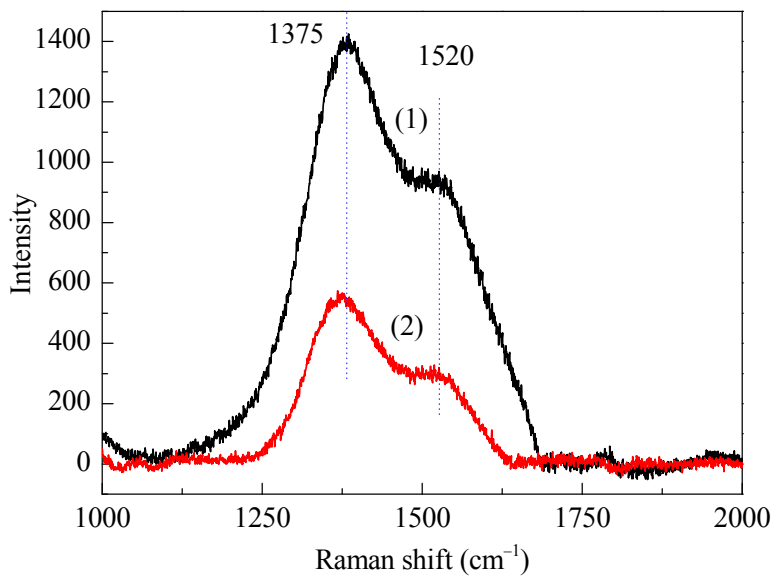

Fig. 4. Raman spectra of the $\mathrm{Pd} / \mathrm{Gr}-\mathrm{N} /$ cordierite (1) and aged $\mathrm{Pd} / \mathrm{Gr}-\mathrm{N} /$ cordierite (2) catalysts.
Table 1

Surface Pd atoms percentage and overall Pd loading.

\begin{tabular}{lcc}
\hline Catalyst & $\begin{array}{c}\text { Surface Pd atoms } \\
\text { percentage (\%) }\end{array}$ & $\begin{array}{c}\text { Overall Pd loading } \\
(\mathrm{mg})\end{array}$ \\
\hline $\mathrm{Pd} / \mathrm{Gr}-\mathrm{N} /$ cordierite & 0.07 & 3.5 \\
$\mathrm{Pd} / \mathrm{Gr} /$ cordierite $^{\mathrm{a}}$ & 0.53 & 1.9 \\
\hline
\end{tabular}

a The Pd catalyst was prepared by another route with poly(diallyldimethylammonium) chloride to modify GO sheets [17].

$\mathrm{Pd} / \mathrm{Gr}-\mathrm{N} /$ cordierite was 1.47. The increase of $I_{\mathrm{D}} / I_{\mathrm{G}}$ may be due to the increase of disorder of the Gr sheets.

The structural change of the Gr coating was probably induced by the dissociation of hydrogen on the Pd particles and its spreading over the interlayers. The large amount of hydrogen atoms absorbed in Pd can result in swelling, erecting, and finally interconnecting of the $\mathrm{Gr}$ sheets to form the grass-like surface. To further understand the role of hydrogen, in a conditioning experiment, only the substrate Gr-N/cordierite was aged under the same condition. No structural change was observed for the $\mathrm{Gr}$ coating. In addition, most Pd particles were loaded into the interlayers, which was shown by the XPS and ICP data shown in Table 1 . The surface content of Pd in Pd/Gr$\mathrm{N} /$ cordierite was much lower than that of $\mathrm{Pd} / \mathrm{Gr} /$ cordierite, which was shown by XPS, but it had a higher overall Pd loading. This contrast revealed that most Pd particles in the Pd/Gr-N/ cordierite catalyst were spread over the interlayers of the $\mathrm{Gr}$ coating, and cannot be detected by XPS. Although the loading of Pd particles into the interlayers of GO sheets was previously reported by Mastalir et al. [22], this is the first time of a report of Pd particles introduced into the interlayers of immobilized Gr sheets.

The initial activity and stability of the $\mathrm{Pd} / \mathrm{Gr}-\mathrm{N} /$ cordierite and Pd/C catalysts in 4-CBA hydrogenation are shown in Fig. 5. The experimental details are given in the supporting information. Figure 5 shows that $\mathrm{Pd} / \mathrm{Gr}-\mathrm{N} /$ cordierite exhibited much higher stability than the $\mathrm{Pd} / \mathrm{C}$ catalyst, although its initial activity was not as high. As for Pd/Gr-N/cordierite, the reaction rate constant $k$ was decreased by only $30 \%$. However, the value of $k$ dropped by almost $92 \%$ for the Pd/C catalyst. As we know, Pd leaching is an important reason for activity loss that is in

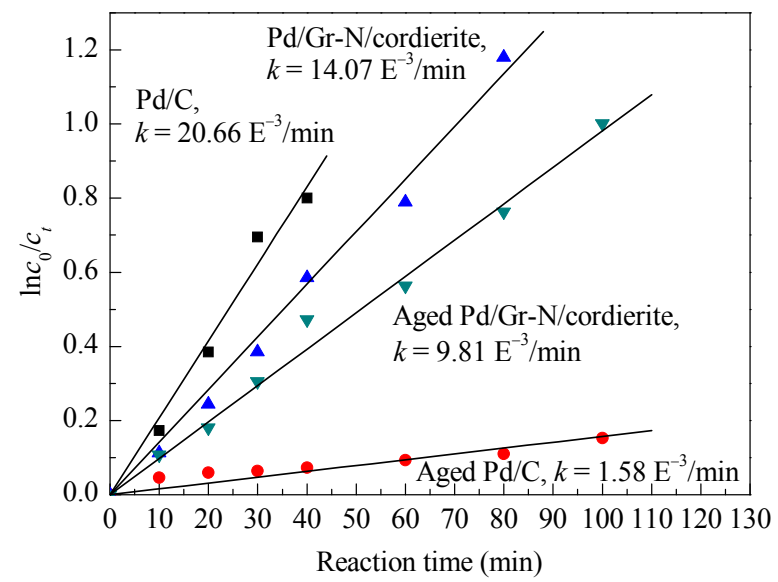

Fig. 5. Initial activity and stability of the Pd/Gr-N/cordierite and Pd/C catalysts. 


\title{
Graphical Abstract
}

Chin. J. Catal., 2015, 36: 148-152 doi: 10.1016/S1872-2067(14)60256-4

Pd confined in grass-like graphene layers on monolithic cordierite as the catalyst for hydrogenation of 4-carboxybenzaldehyde

Gonggang Liu, Linyu Yu, Yuchao Zhu, Xiaoguang Guo, Yonghua Zhou*, Hongqi Ye*

Central South University;

Dalian Institute of Chemical Physics, Chinese Academy of Sciences

A very stable Pd catalyst confined in grass-like graphene layers on monolithic cordierite was developed by utilizing $\mathrm{NH}_{2}$-ion liquid $\mathrm{C}_{7} \mathrm{H}_{14} \mathrm{ClN}_{3}$ functionalized graphene.

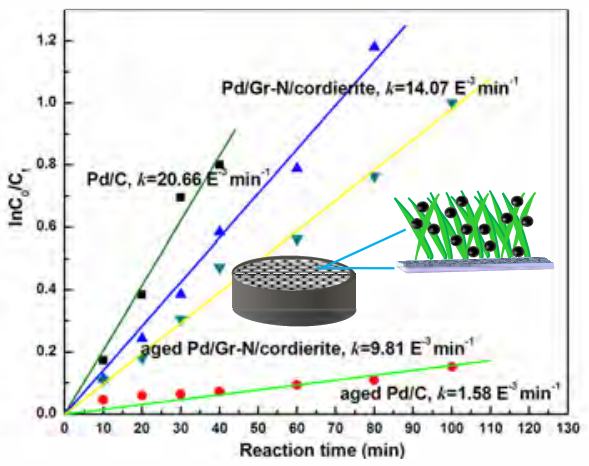

Table 2

$\mathrm{Pd}$ loading before and after aging of $\mathrm{Pd} / \mathrm{Gr}-\mathrm{N} /$ cordierite and $\mathrm{Pd} / \mathrm{C}$ catalysts.

\begin{tabular}{lccc}
\hline \multirow{2}{*}{ Catalyst } & \multicolumn{2}{c}{ Pd loading (\%) } & \multirow{2}{*}{$\begin{array}{c}\text { Pd leaching } \\
\text { (\%) }\end{array}$} \\
\cline { 2 - 3 } & Before aging & After aging & \\
\hline Pd/Gr-N/cordierite & 0.0219 & 0.0208 & 5 \\
Pd/C & 0.550 & 0.350 & 36 \\
\hline
\end{tabular}

addition to Pd aggregation. To illustrate the two aspects, the contrast of Pd loading before and after aging is shown in Table 2. For Pd/Gr-N/cordierite, the Pd leaching percentage was obviously reduced from $36 \%$ to $5 \%$, as compared with Pd/C. So, the contribution of $\mathrm{Pd}$ aggregation to activity loss for $\mathrm{Pd} / \mathrm{Gr}-\mathrm{N} /$ cordierite and $\mathrm{Pd} / \mathrm{C}$ can be calculated to be $25 \%$ and $56 \%$, respectively.

In summary, a novel monolithic Pd/Gr-N/cordierite catalyst was developed by utilizing $\mathrm{NH}_{2}$-IL modified $\mathrm{Gr}$ sheets. The catalyst showed excellent stability for 4-CBA hydrogenation as compared to a commercial $\mathrm{Pd} / \mathrm{C}$ catalyst. The grass-like surface structure of the Gr sheets on cordierite was achieved after aging under 4-CBA hydrogenation condition. The grass-like surface structure prevented Pd leaching and aggregation, which led to improved stability. In addition, the monolithic cordierite with the $\mathrm{Gr}$ coating possessed high mechanical strength and acid corrosion resistance. Therefore, $\mathrm{Pd} / \mathrm{Gr}-\mathrm{N} /$ cordierite is a promising catalyst for CTA purification in industry.

\section{References}

[1] Romanenko A V, Tyschishin E A, Moroz E M, Likholobov V A, Zaikovskii V I, Jhung S H, Park Y S. Appl Catal A, 2002, 227: 117

[2] Menegazzo F, Fantinel T, Signoretto M, Pinna F. Catal Commun, 2007, 8: 876

[3] Li XY, Pan X L, Zhou Y H, Bao X H. Carbon, 2013, 57: 34
[4] Pellegrini R, Agostini G, Groppo E, Piovano A, Leofanti G, Lamberti C. J Catal, 2011, 280: 150

[5] Jhung S H, Romanenko A V, Lee K H, Park Y S, Moroz E M, Likholobov V A. Appl Catal A, 2002, 225: 131

[6] Cagnola E A, Quiroga M E, Liprandi D A, L'Argentière P C. Appl Catal A, 2004, 274: 205

[7] Cheng D J, Wang W C. Nanoscale, 2012, 4: 2408

[8] Yu Y Z, Gutiérrez O Y, Haller G L, Colby R, Kabius B, Van Veen J A R, Jentys A, Lercher J A. J Catal, 2013, 304: 135

[9] Zhou Y H, Li X Y, Pan X L, Bao X H.J Mater Chem, 2012, 22: 14155

[10] Coulston N J, Wells R P K, Wells P B, Hutchings G J. Catal Today, 2006, 114: 353

[11] Kou R, Shao Y Y, Mei D H, Nie Z M, Wang D H, Wang C M, Viswanathan V V, Park S, Aksay I A, Lin Y H, Wang Y, Liu J. J Am Chem Soc, 2011, 133: 2541

[12] Li K T, Hsu M H, Wang I. Catal Commun, 2008, 9: 2257

[13] Tessonnier J P, Pesant L, Ehret G, Ledoux M J, Pham-Huu C. Appl Catal A, 2005, 288: 203

[14] Scheuermann G M, Rumi L, Steurer P, Bannwarth W, Mülhaupt R.J Am Chem Soc, 2009, 131: 8262

[15] Siamaki A R, Khder A E R S, Abdelsayed V, El-Shall M S, Gupton B F. J Catal, 2011, 279: 1

[16] Zhu Y C, Yu L Y, Wang X F, Zhou Y H, Ye H Q. Catal Commun, 2013, 40: 98

[17] Zhu Y C, Zhou Y H, Yu L Y, Liu G G, Tian Y X, Ye H Q. RSC Adv, 2014, 4: 9480

[18] Han K, Shen J M, Hao S Q, Ye H Q, Wolverton C, Kung M C, Kung H H. ChemSusChem, 2014, 7: 2545

[19] Algi F. Tetrahedron, 2013, 69: 3523

[20] Wang Z W, Li B, Xin Y C, Liu J G, Yao Y F, Zou Z G. Chin J Catal (汪忠 伟, 黎波, 辛宇尘, 刘建国, 姚颖方, 邹志刚. 催化学报), 2014, 35: 509

[21] Sheng Z H, Shao L, Chen J J, Bao W J, Wang F B, Xia X H. ACS Nano, 2011, 5: 4350

[22] Mastalir A, Kiraly Z, Patzko A, Dekany I, L'Argentiere P. Carbon, 2008, 46: 1631

\section{草簇状石墨烯片限域Pd纳米粒子及其催化应用}

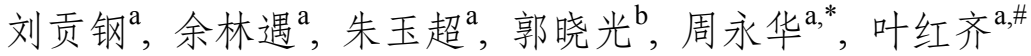 \\ ${ }^{\mathrm{a}}$ 中南大学化学化工学院, 湖南长沙 410083 \\ ${ }^{\mathrm{b}}$ 中国科学院大连化学物理研究所催化基础国家重点实验室, 辽宁大连 116023
}


摘要: 通过氨基离子液体改性石墨烯, 并将其固载于堇青石表面, 作为负载型Pd催化剂的载体. 所制备的Pd催化剂经加氢老化后, 表面石墨烯呈草簇状结构, 将Pd纳米粒子限域于片层内, 有效防止了 Pd的流失和团聚. 在重要的工业反应对羧基苯甲醛(4-CBA) 加氢中, 此结构催化剂与传统的钯碳催化剂相比, 表现出很好的稳定性.

关键词: 钯催化剂; 草簇状结构石墨烯; 对羧基苯甲醛; 加氢

收稿日期: 2014-09-15. 接受日期: 2014-11-11. 出版日期: 2015-02-20.

*通讯联系人. 电话/传真：(0731)88876605; 电子信箱：zhouyonghua@mail.csu.edu.cn

\#通讯联系人. 电话/传真: (0731)88876605; 电子信箱: yeslab@mail.csu.edu.cn

基金来源：国家自然科学基金(21006129,21276284和21146008).

本文的英文电子版由Elsevier出版社在ScienceDirect上出版(http://www.sciencedirect.com/science/journal/18722067). 